\title{
SISTEM INFORMASI E-ARSIP KELURAHAN CAKRANEGARA UTARA
}

\author{
(E-Archive Information Systems Of Northern Cakranegara Village)
}

\author{
Ida Ayu Vigi Meidhyana Putri ${ }^{[1]}$, I Gde Putu Wirarama ${ }^{[1]}$, I Made Suta ${ }^{[2]}$ \\ ${ }^{[1]}$ Dept Informatics Engineering, Mataram University \\ J1. Majapahit 62, Mataram, Lombok, NTB, INDONESIA \\ ${ }^{[2]}$ Kelurahan Cakranegara Utara \\ J1. Gora No. 25, Cakranegara, Lombok, NTB, INDONESIA
}

Email: idaayuvigi03@gmail.com,wirarama@unram.ac.id, imadesuta@gmail.com

\begin{abstract}
Abstrak
Hingga saat ini pengelolaan arsip pada Kelurahan Cakranegara Utara masih dilakukan secara manual atau konvensional sehingga menyebabkan sering terjadinya kesalahan dalam penyimpanan dan pencarian data arsip. Padahal arsip merupakan dokumen penting yang disimpan dengan tujuan apabila dibutuhkan kembali akan mudah untuk menemukannya, maka sangat diharapkan proses pengelolaan arsip dilakukan dengan baik, cepat, dan mudah dengan memanfaatkan teknologi yang ada saat ini. Oleh karena itu sistem informasi e-arsip berbasis website menggunakan framework CodeIgniter dan Bootstrap ini dibuat dengan tujuan untuk mengubah cara pengelolaan dan pengarsipan data arsip yang semula hard copy menjadi soft copy. Metode yang digunakan dalam pembuatan sistem yaitu metode waterfall dengan urutan tahapan dari analisis kebutuhan, desain sistem, coding dan testing, penerapan program, serta pemeliharaan. Pengujian sistem dilakukan dengan menggunakan user acceptance testing yang di dalamnya terdapat pengujian black box dan kuisioner yang kemudian didapatkan hasil bahwa responden 100\% setuju bahwa sistem informasi yang dibuat dapat membantu pegawai dan telah berjalan dengan baik.
\end{abstract}

Keywords: E-Arsip, CodeIgniter, Bootstrap, Arsip, Metode Waterfall, User Acceptance Testing.

\section{Pendahuluan}

\subsection{Latar Belakang}

Di era globalisasi ini perkembangan teknologi dari waktu ke waktu begitu pesat sehingga membuat pekerjaan manusia dipermudah dengan adanya teknologi saat ini, yang pada umumnya akan diselesaikan dengan cepat. Teknologi merupakan salah satu alat bantu yang sering digunakan pada aktivitas manusia, yang mana perannya begitu penting seperti halnya dalam mendapatkan suatu informasi dengan cepat maupun mendata suatu informasi [1]. Teknologi mampu mengolah suatu data dengan efesien dan terstruktur yang dapat dimanfaatkan oleh setiap instansi atau organisasi untuk meningkatkan produktivitas, waktu, dan biaya.

Kantor Kelurahan Cakranegara Utara adalah salah satu kantor pelayanan kependudukan yang bertanggung jawab untuk memberikan layanan kepada masyarakat. Selama ini, kantor kelurahan Cakranegara Utara telah melayani masyarakat di wilayah Cakranegara bagian utara untuk membantu masyarakat mendapatkan kebutuhan-kebutuhan seperti Surat Keterangan Catatan Kepolisian (SKCK), Surat Pengantar Kartu Tanda Penduduk (KTP), dan berbagai macam jenis surat lainnya. Surat memiliki fungsi yang sangat penting dan dapat digunakan sebagai dokumen karena memiliki bukti tanda tangan [2]. Tetapi pada saat ini, kantor Kelurahan Cakranegara Utara belum memiliki sistem atau basis data informasi yang digunakan untuk melakukan pengelolaan arsip data surat sehingga masih dilakukan secara manual, dimana hal ini akan memperlambat kinerja pegawai kantor Kelurahan Cakranegara Utara. Sebagai kantor pelayanan masyarakat, Kelurahan Cakranegara Utara berharap dapat memiliki sistem yang baik yang digunakan untuk memberikan pelayanan yang mudah, cepat, dan tepat.

Oleh karena itu penulis mencoba mencari solusinya agar kantor Kelurahan Cakranegara Utara dapat menyediakan dan melakukan pengelolaan data surat-surat dengan mudah, cepat, dan tepat dengan membuat sistem pengarsipan elektronik berbasis website dengan judul "Sistem Informasi E-Arsip Kelurahan Cakranegara Utara Berbasis Website". Dengan adanya pengarsipan data yang terkomputerisasi pada kantor Kelurahan Cakranegara Utara diharapkan dapat memberikan pelayanan dengan mudah, cepat, dan tepat, serta mempermudah pegawai kantor untuk melakukan pengelolaan data surat-surat. 


\section{Tinjauan Pustaka}

Sistem informasi adalah kumpulan komponen yang saling terhubung dalam mengumpulkan, memproses, menyimpan, menyediakan dan mendistribusikan informasi untuk mendukung pengambilan keputusan dan pengendalian di dalam organisasi [3]. Pengertian lain mengatakan bahwa sebuah sistem informasi merupakan sekumpulan dari perangkat keras dan perangkat lunak. Selain itu data juga memegang peranan penting dalam sistem informasi. Data yang akan dimasukkan dalam sebuah sistem informasi yaitu dapat berupa formulir-formulir, prosedur-prosedur, dan bentuk data lainnya [4].

Database atau basis data merupakan sekumpulan data yang saling berintegrasi antara satu sama lain dan terorganisasi berdasarkan sebuah skema atau struktur tertentu dan tersimpan pada sebuah komputer. Database terdiri dari beberapa tabel atau lebih dari satu tabel yang saling terorganisir untuk menyimpan data dan terdiri dari baris dan kolom. Data yang tersimpan pada tabel diantaranya dapat ditampilkan, dimodifikasi dan dihapus. Setiap pemakai (user) diberi wewenang untuk dapat melakukan akses data tersebut [5].

World Wide Web atau yang biasa disebut website dapat diartikan sebagai kumpulan halaman-halaman yang digunakan untuk mempublikasikan informasi berupa teks, gambar, dan program multimedia lainnya berupa animasi suara dan atau gabungan dari semua itu baik yang bersifat statis maupun dinamis yang saling terkait antara satu halaman dengan halaman yang sering disebut dengan hyperlink [6]. Pada website statis komunikasi berjalan secara satu arah dari server ke client sedangkan website dinamis komunikasinya berjalan secara dua arah dimana user bisa memasukkan data tertentu ke halaman web untuk kemudian diproses oleh server dan menghasilkan output yang diinginkan oleh user [7].

Unified Modelling Language (UML) merupakan alat perancangan sistem yang berorientasi pada objek yang memiliki tujuan utama untuk membantu tim pengembangan proyek berkomunikasi, mengeskplorasi potensi desain, dan memvalidasi desain arsitektur perangkat lunak atau membuat program [8]. UML adalah salah satu standar Bahasa yang banyak digunakan di dunia industry untuk mendefinisikan requirement, membuat analisis dan desain, serta menggambarkan arsitektur dalam pemrograman berorientasi objek [9].

ERD (Entity Relationship Diagram) merupakan sebuah diagram yang digunakan untuk merancang hubungan antar tabel-tabel dalam basis data [10]. ERD (Entity Relation Diagram) berguna untuk menggambarkan gambaran dari dunia nyata yang akan diterapkan pada suatu database sebuah sistem. ERD melihat objek nyata dapat sebagai sebuah entitas - entitas yang memiliki relasi antara entitas yang satu ataupun yang lain

PHP merupakan software digunakan sebagai Bahasa script server-side dalam pengembangan web yang disisipkan pada dokumen HTML [11]. PHP (Hypertext Preprocessor) disebut sebagai Bahasa pemrograman server side karena diproses pada komputer server saja. Dengan menggunakan PHP, pembuatan web dimudahkan dalam membuat konten di dalam sebuah halaman karena lebih efektif. Misalnya, untuk melakukan pengulangan secara lebih efektif, meng-input database, dan sebagainya [12].

MySQL adalah salah satu aplikasi DBMS yang sudah sangat banyak digunakan oleh para programmer aplikasi web. Sampai saat ini MySQL masih menjadi DBMS paling banyak digunakan di dunia. MySQL terkenal dengan kecepatan dalam pengaksesan datanya [13].

CodeIgniter merupakan sebuah framework PHP yang bersifat open source dan menggunakan metode MVC (Model, View, Controller) untuk memudahkan developer atau programmer dalam membangun sebuah aplikasi berbasis web tanpa harus membuatnya dari awal. Sedangkan framework adalah kumpulan instruksi-instruksi yang dikumpulkan dalam class dan function-function dengan fungsi masing-masing untuk memudahkan developer dalan memanggilnya tanpa harus menulis syntax program yang sama berulang-ulang serta dapat menghemat waktu [14].

XAMPP adalah perangkat lunak bebas yang mendukung banyak sistem informasi, merupakan kompilasi dari beberapa program. Fungsinya adalah sebagai server yang berdiri sendiri (localhost), yang terdiri atas program Apache, HTTP server, MySQL database, dan penerjemah Bahasa yang ditulis dengan Bahasa pemrograman PHP dan Perl [13].

Bootstrap merupakan framework untuk membangun desain web secara responsive. Artinya, tampilan web yang dibuat oleh bootstrap akan menyesuaikan ukuran layerdan browser yang kita gunakan baik di desktop, tablet ataupun mobile device. Dengan bootstrap kita juga bisa membangun web dinamis ataupun statis [14].

\section{Metode Pengabdian Masyarakat}

\subsection{Metode Perancangan Sistem Untuk Masyarakat Pada Kantor Kelurahan Cakranegara Utara}

Metode yang digunakan dalam perancangan sistem informasi pengarsipan surat pada Kelurahan Cakranegara Utara ini adalah metode waterfall. Alasan penggunaan metode waterfall dalam pembuatan sistem informasi e-arsip ini dikarenakan sistem yang dibuat tidak terlalu besar dan lingkup pengembangannya tidak begitu luas sehingga 
akan lebih memudahkan jika menggunakan metode waterfall yang pendekatannya dilakukan secara sistematis dan berurutan.

Secara garis besar, metode pengembangan perangkat lunak dengan metode waterfall dibagi menjadi lima tahapan utama, yaitu analisa kebutuhan masyarakat yang bertujuan untuk menganalisis kebutuhan yang dibutuhkan oleh masyarakat keluarahan cakranegara utara, baik berupa dokumen maupun sumber lain yang dapat membantu dalam menentukan solusi permasalahan yang ada, perancangan sistem untuk masyarakat (design) untuk menyediakan sistem informasi yang terorganisir dengan baik yang menggunakan beberapa diagram serta mockup sistem, pembuatan kode program (coding) sesuai dengan analisis kebutuhan untuk membuat sistem berbasis website dengan Bahasa pemrograman PHP, pengujian (testing), serta pendukung (support) dan pemeliharaan (maintanance) [16]. Berikut gambaran dari tahapan-tahapan pada metode waterfall:

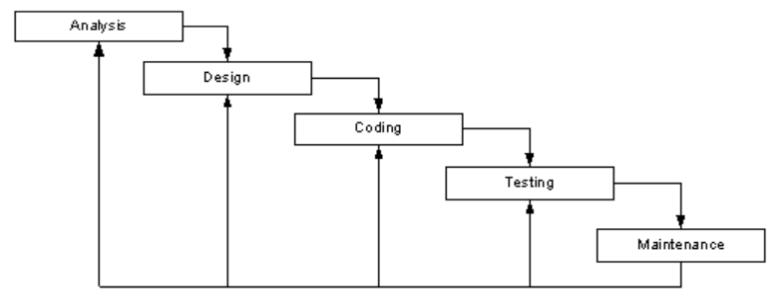

Gambar 1. Metode waterfall

\subsection{Desain Sistem}

Sistem Informasi E-Arsip Kelurahan Cakranegara Utara memiliki beberapa diagram seperti Use Case Diagram, Class Diagram, Sequence Diagram, Activity Diagram, dan Entity Relationship Diagram.

\subsubsection{Use Case Diagram}

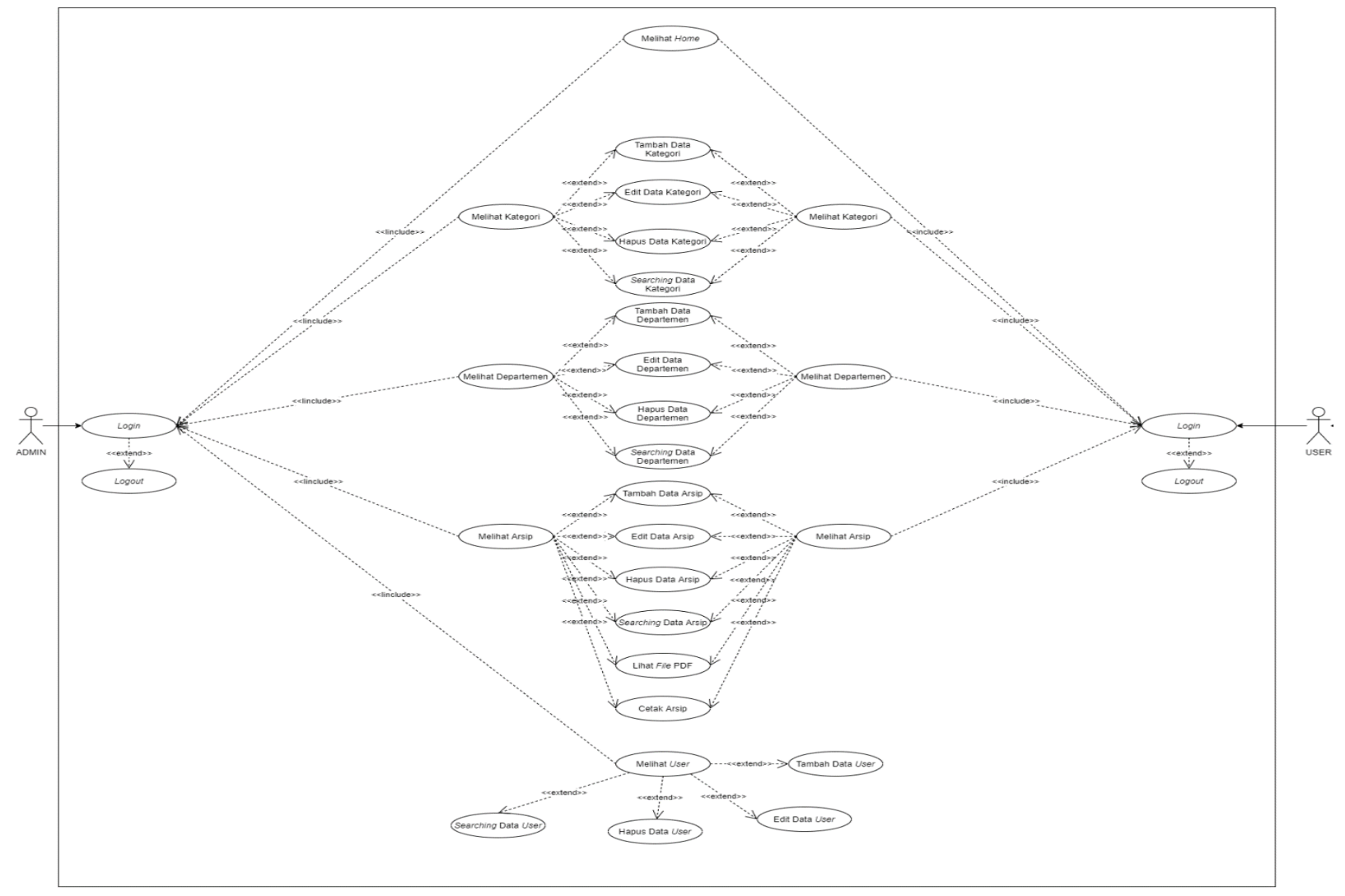

Gambar 2. Use case diagram e-arsip

Pada Gambar 2 dapat dilihat bahwa dalam use case diagram tersebut terdapat dua aktor yaitu administrator dan user. Adapun tugas administrator dan user dijabarkan sebagai berikut:

1. Administrator 
Dapat melihat home, melihat dan mengedit menu kategori, melihat dan mengedit menu departemen (melakukan tambah data, edit data, hapus data, dan searching data), melihat dan mengedit menu, serta melihat dan mengedit menu user.

2. User

Dapat melihat home, melihat dan mengedit menu kategori, melihat dan mengedit menu departemen, serta melihat dan mengedit menu.

\subsubsection{Class Diagram}

Class diagram dari sistem informasi e-arsip pada Kelurahan Cakranegara Utara adalah sebagai berikut:

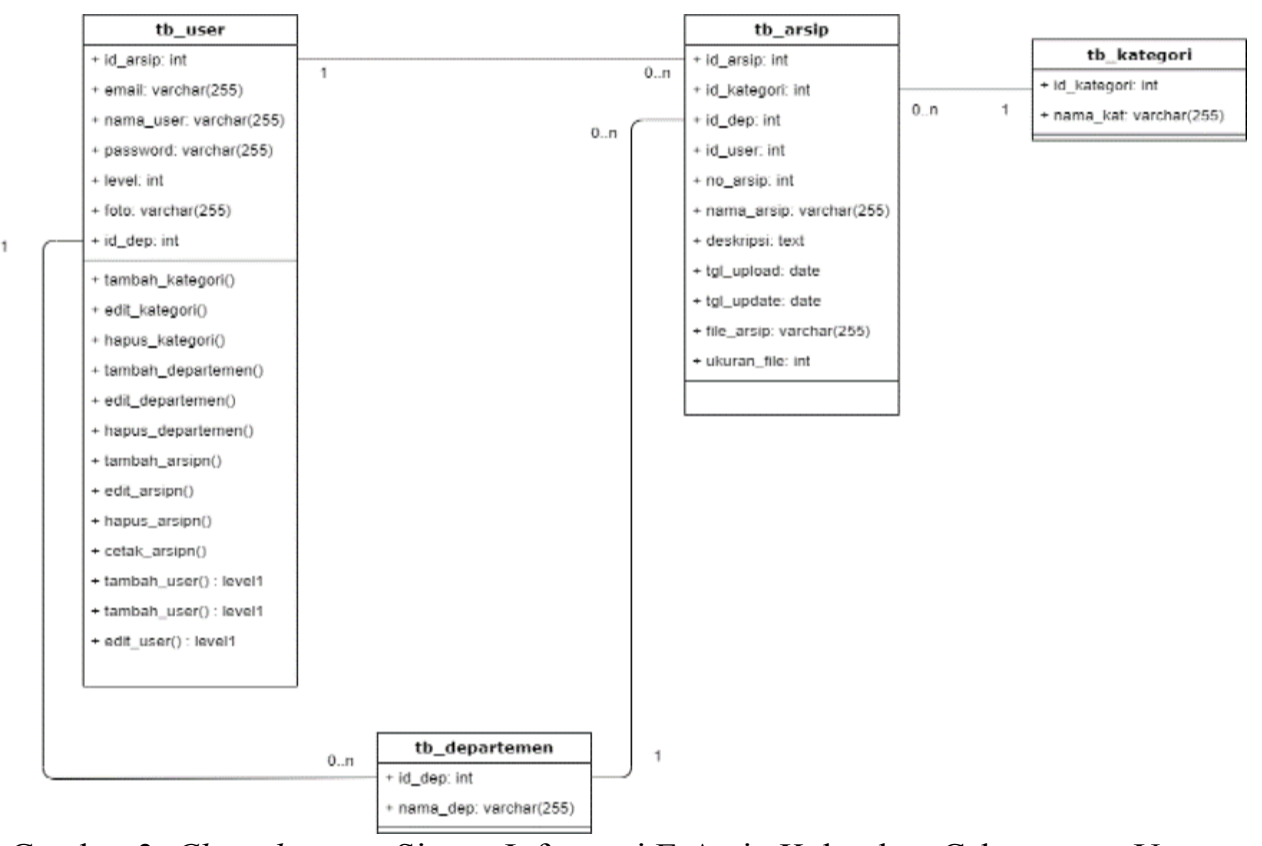

Gambar 3. Class diagram Sistem Informasi E-Arsip Kelurahan Cakranegara Utara

\subsubsection{Entity Relationship Diagram}

Entity relationship diagram Sistem Informasi E-arsip Kelurahan Cakranegara Utara adalah sebagai berikut:

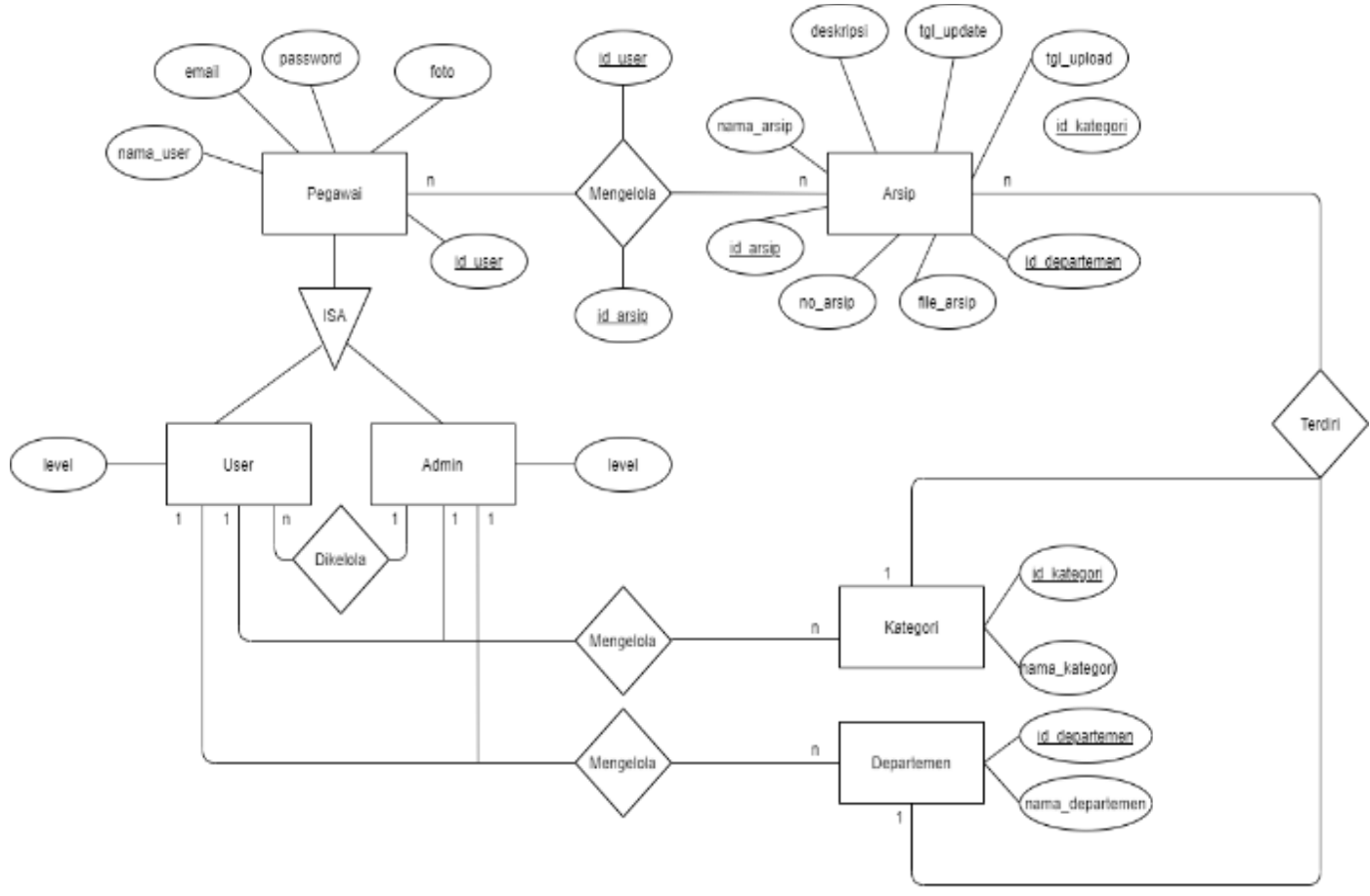

Gambar 4. Entity relationship diagram Sistem Informasi E-Arsip Kelurahan Cakranegara Utara 


\section{Hasil dan Pembahasan}

\subsection{Implementasi Sistem}

Implementasi sistem merupakan tahap penerapan serta pengujian untuk sistem berdasarkan hasil analisa dan perancangan yang dilakukan. Implementasi sistem telah disesuaikan dengan perancangan pada sub-sub bab sebelumnya. Berikut merupakan implementasi sistem dari Sistem Informasi E-arsip Kelurahan Cakranegara Utara: 1. Halaman Login

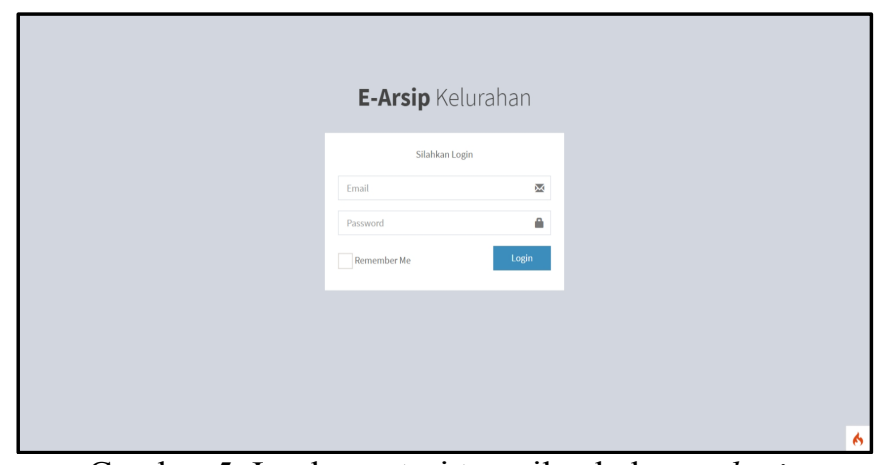

Gambar 5. Implementasi tampilan halaman login

Pada Gambar 5 merupakan implementasi tampilan halaman login ketika pegawai pertama kali membuka website e-arsip. Pada halaman ini pegawai terlebih dahulu harus memasukkan email dan password untuk dapat menggunakan website.

\section{Halaman Home}

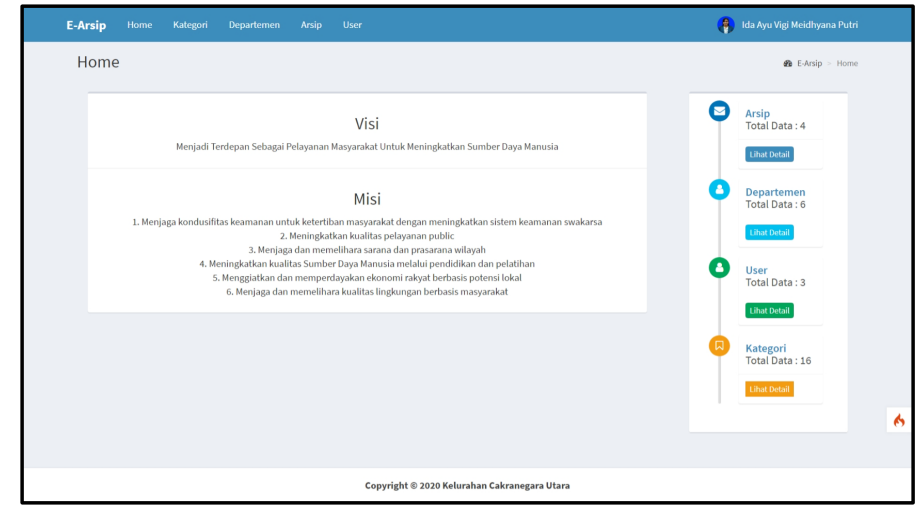

Gambar 6. Implementasi tampilan halaman home admin

Pada Gambar 6 merupakan implementasi tampilan home ketika pegawai sebagai admin berhasil melakukan login pada website. Pada halaman ini terdapar informasi "Visi dan Misi" dari Kelurahan Cakranegara Utara, dan terdapat informasi singkat mengenai total jumlah data dari tiap menu yang ada, seperti total data: "Arsip", "Departemen", "Kategori", dan "User". Kemudian pada navbar terdapat menu "Kategori”, "Departemen", "Arsip", "User" dan informasi mengenai akun pegawai yang digunakan untuk login seperti menampilkan foto dan nama pegawai tersebut. Pada bagian footer terdapat keterangan "Copyright 2020 Kelurahan Cakranegara Utara".

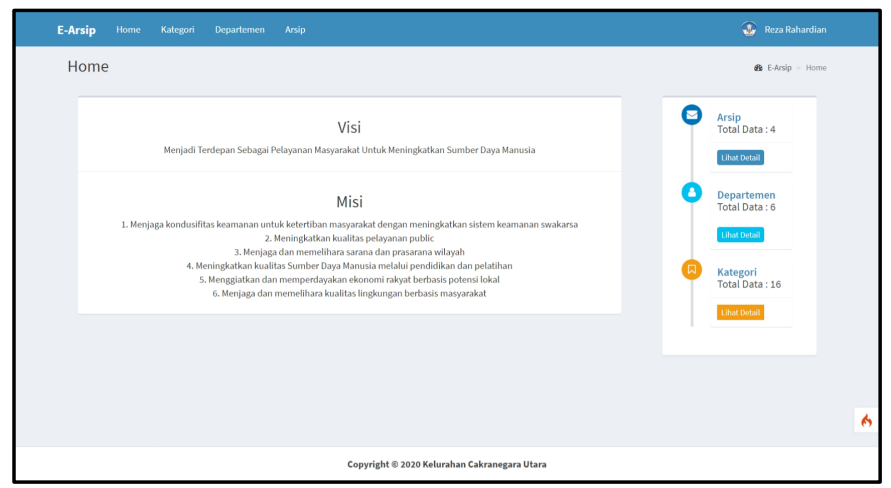

Gambar 7. Implementasi tampilan halaman home user 
Pada Gambar 7 merupakan implementasi tampilan home ketika pegawai sebagai user berhasil melakukan login pada website. Pada halaman ini sama seperti tampilan home pada home admin, perbedaannya adalah pada tampilan halaman ini menu "User" tidak ada karena menu "User" hanya dapat diakses oleh admin saja.

3. Halaman Kategori

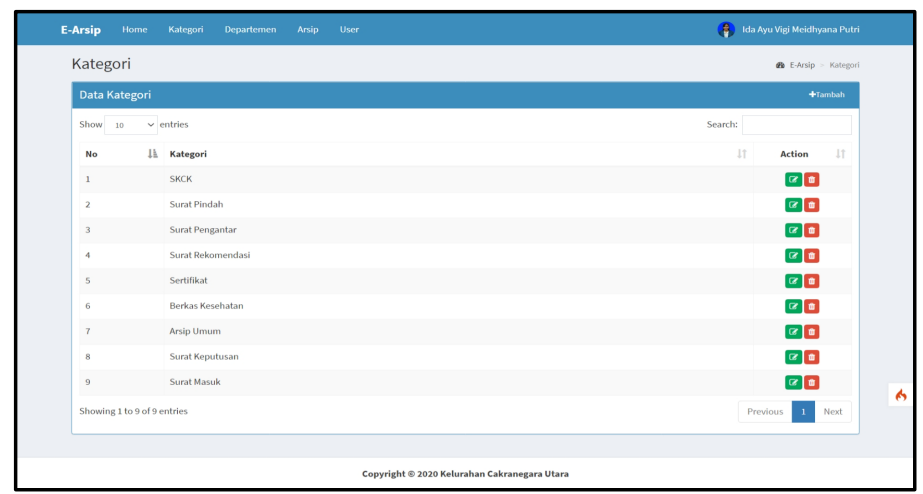

Gambar 8. Implementasi tampilan kategori

Pada Gambar 8 merupakan implementasi tampilan menu kategori. Pada halaman ini terdapat tabel Data Kategori dengan kolom "No", "Kategori", dan "Action". Pada pojok kanan atas tabel terdapat tombol yang dapat digunakan untuk menambahkan data kategori. Kemudian terdapat kolom pencarian yang digunakan oleh pegawai untuk melakukan pencarian sesuai data yang diinginkan. Pada kolom "Action" terdapat tombol edit berwarna hijau yang digunakan untuk melakukan perubahan data kategori, dan tombol hapus berwarna merah yang digunakan untuk menghapus data kategori.

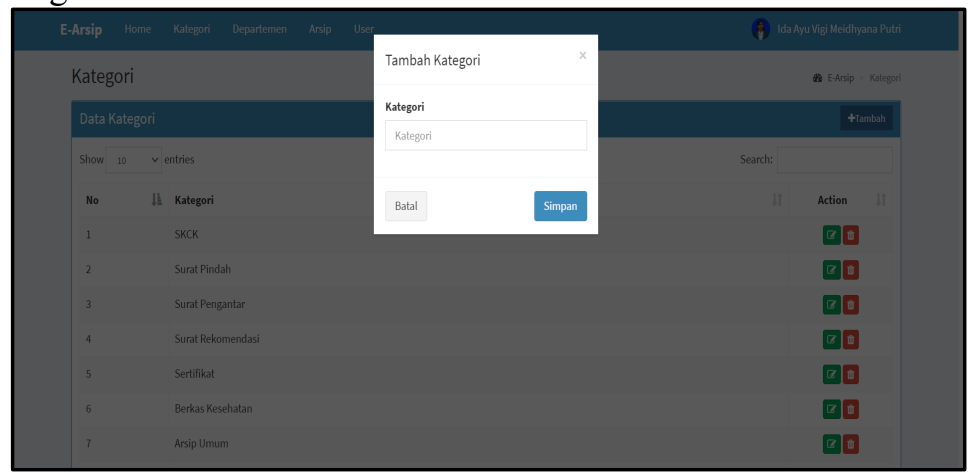

Gambar 9. Implementasi tampilan tambah kategori

Pada Gambar 9 merupakan tampilan tambah data kategori. Ketika user mengklik tombol tambah pada tabel Data Kategori maka akan muncul window untuk menambahkan data kategori. Pada tampilan ini terdapat tombol simpan yang digunakan ketika user ingin melakukan penambahan data sesuai yang dimasukkan pada kolom input dan tombol batal yang digunakan ketika user batal melakukan penambahan pada data kategori.

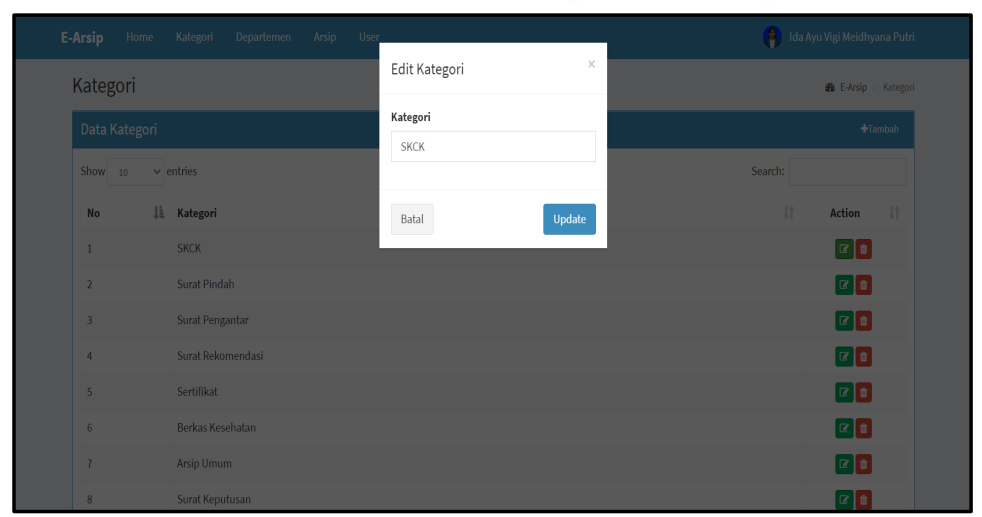

Gambar 10. Implementasi tampilan edit kategori

Pada Gambar 10 merupakan implementasi tampilan edit data kategori. Ketika user mengklik tombol edit berwarna hijau pada kolom action maka akan muncul window untuk melakukan edit data kategori. Pada tampilan 
ini terdapat tombol update yang digunakan ketika user ingin melakukan perubahan data sesuai yang dimasukkan pada kolom input dan tombol batal yang digunakan ketika user batal melakukan perubahan pada data kategori.

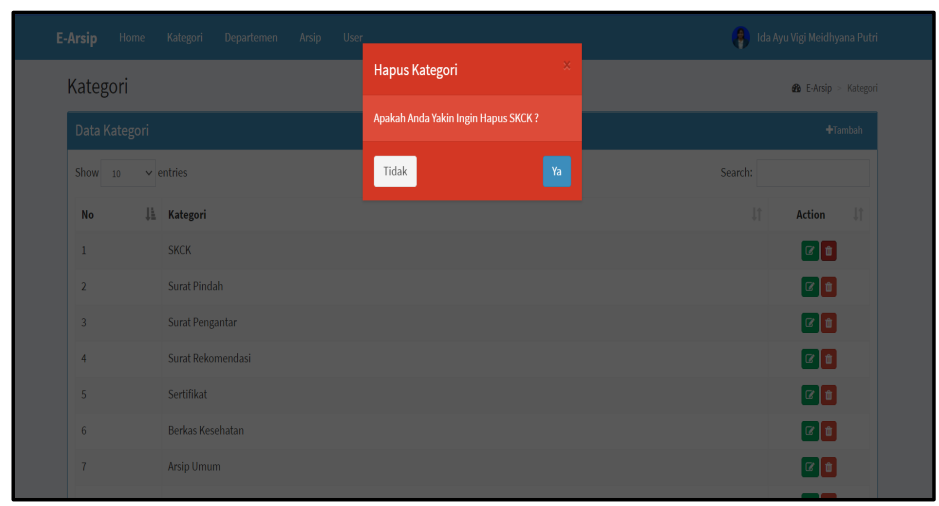

Gambar 11. Implementasi tampilan hapus kategori

Pada Gambar 11 merupakan implementasi tampilan hapus data kategori. Ketika user mengklik tombol hapus berwarna merah pada kolom action maka akan muncul window untuk melakukan hapus data kategori. Pada tampilan ini terdapat tombol "Ya" yang digunakan ketika user yakin akan menghapus data kategori dan tombol "Tidak" yang digunakan ketika user batal melakukan penghapusan data kategori.

4. Halaman Departemen

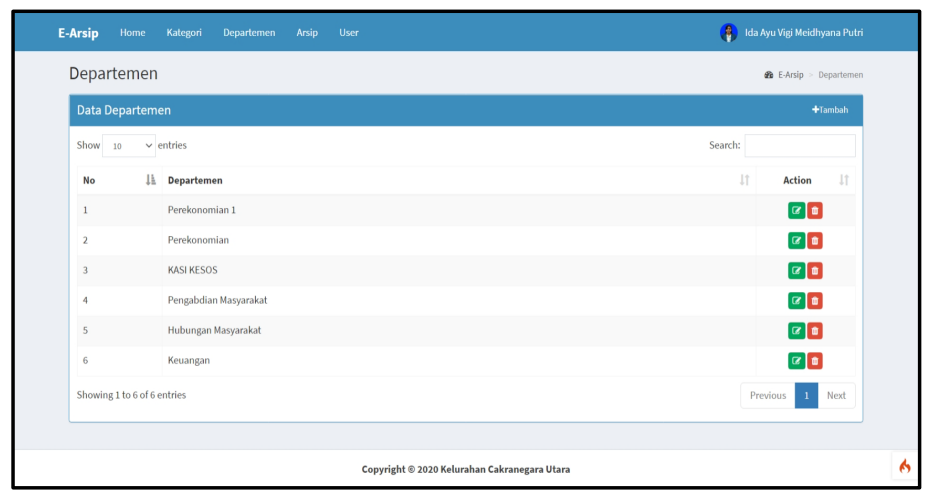

Gambar 12. Implementasi tampilan menu departemen

Pada Gambar 12 merupakan implementasi tampilan menu kategori. Pada halaman ini terdapat tabel Data Departemen dengan kolom "No", "Departemen", dan "Action". Pada pojok kanan atas tabel terdapat tombol yang dapat digunakan untuk menambahkan data departemen. Kemudian terdapat kolom pencarian yang digunakan oleh pegawai untuk melakukan pencarian sesuai data untuk melakukan perubahan pada departemen, dan tombol hapus berwarna merah yang digunakan untuk menghapus data departemen.

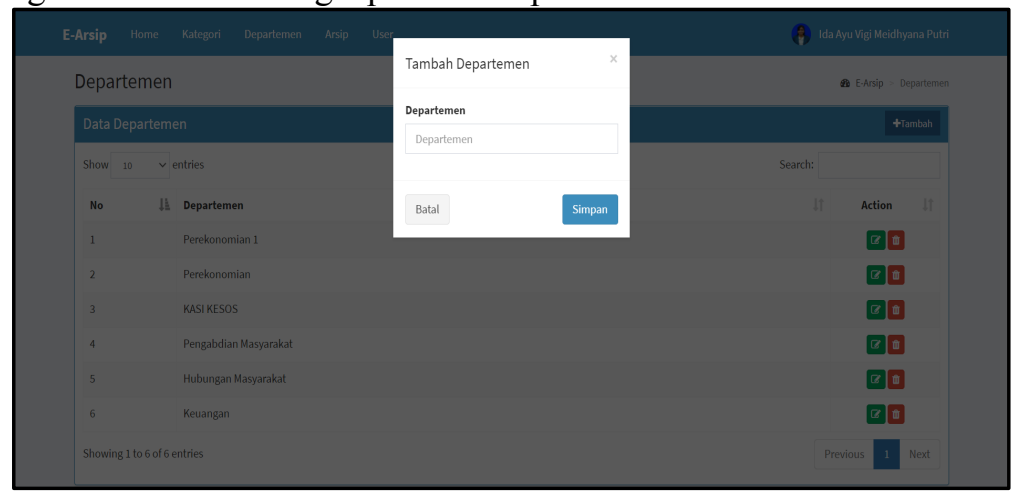

Gambar 13. Implementasi tampilan tambah departemen

Pada Gambar 13 merupakan implementasi tampilan tambah data departemen. Ketika user mengklik tombol tambah pada tabel Data Departemen maka akan muncul window untuk menambahkan data departemen. Pada tampilan ini terdapat tombol simpan yang digunakan ketika user ingin melakukan penambahan data sesuai yang dimasukkan pada kolom input dan tombol batal yang digunakan ketika user batal melakukan penambahan data departemen. 


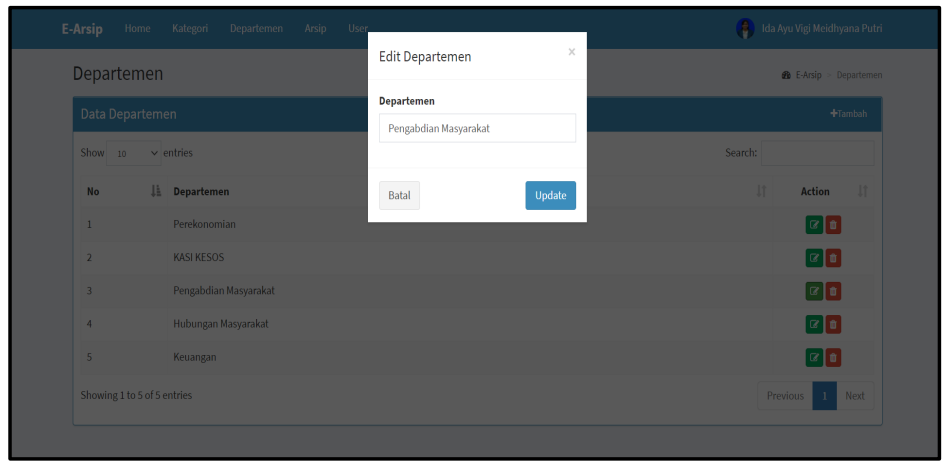

Gambar 14. Implementasi tampilan edit departemen

Pada Gambar 14 merupakan implementasi tampilan edit data departemen. Ketika user mengklik tombol edit berwarna hijau pada kolom action maka akan muncul window untuk melakukan edit data departemen. Pada tampilan ini terdapat tombol update yang digunakan ketika user ingin melakukan perubahan data sesuai yang dimasukkan pada kolom input dan tombol batal yang digunakan ketika user batal melakukan perubahan pada data departemen.

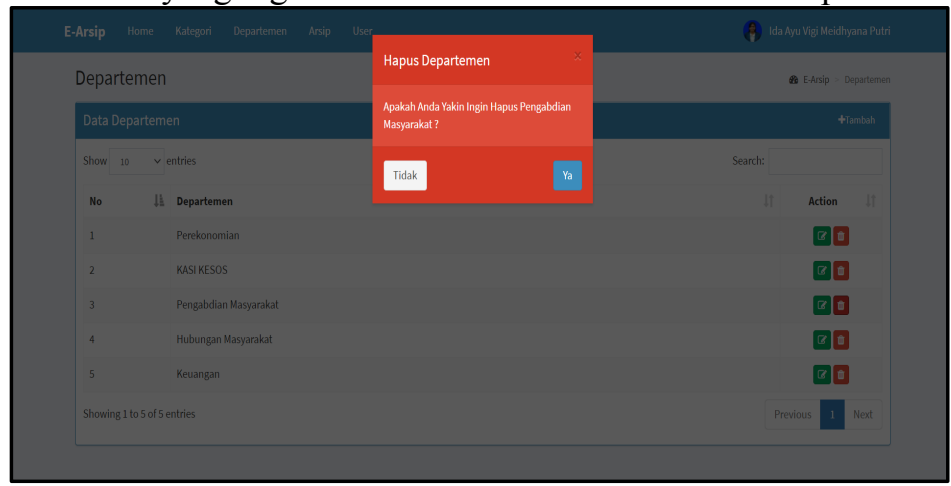

Gambar 15. Implementasi tampilan hapus departemen

Pada Gambar 15 merupakan implementasi tampilan hapus data departemen. Ketika user mengklik tombol hapus berwarna merah pada kolom action maka akan muncul window untuk melakukan hapus data departemen. Pada tampilan ini terdapat tombol "Ya" yang digunakan ketika user yakin akan menghapus data departemen dan tombol "Tidak" yang digunakan ketika user batal melakukan penghapusan pada data departemen.

5. Halaman Arsip

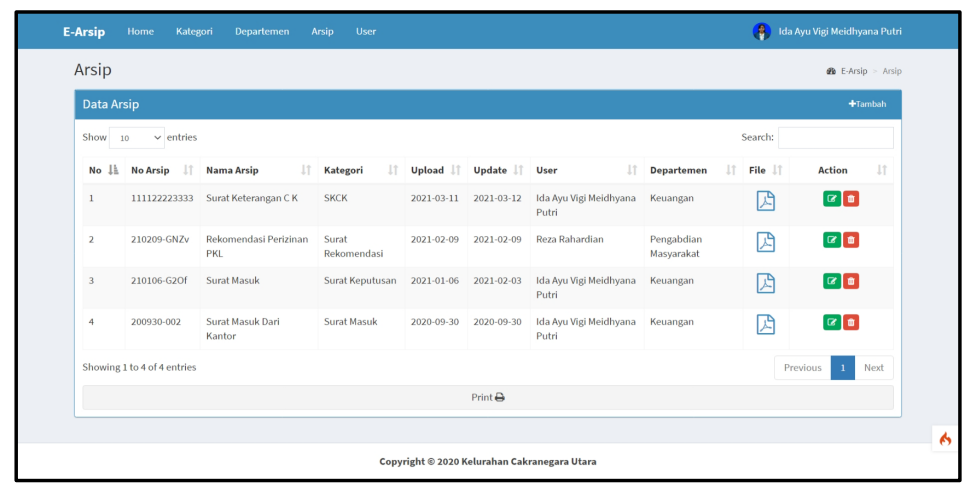

Gambar 16. Implementasi tampilan menu arsip

Pada Gambar 16 merupakan implementasi tampilan menu arsip. Pada halaman ini terdapat tabel Data Arsip dengan kolom "No", "No Arsip", "Kategori", "Upload", "Update", "User", "Departemen", "File", dan "Action". Pada pojok kanan atas tabel terdapat tombol yang dapat digunakan untuk menambahkan data arsip. Kemudian terdapat kolom pencarian yang digunakan oleh pegawai untuk melakukan pencarian sesuai data yang diinginkan. Pada kolom "Action" terdapat tombol edit berwarna hijau yang digunakan untuk melakukan perubahan pada arsip dan tombol hapus berwarna merah yang digunakan untuk menghapus data arsip. 


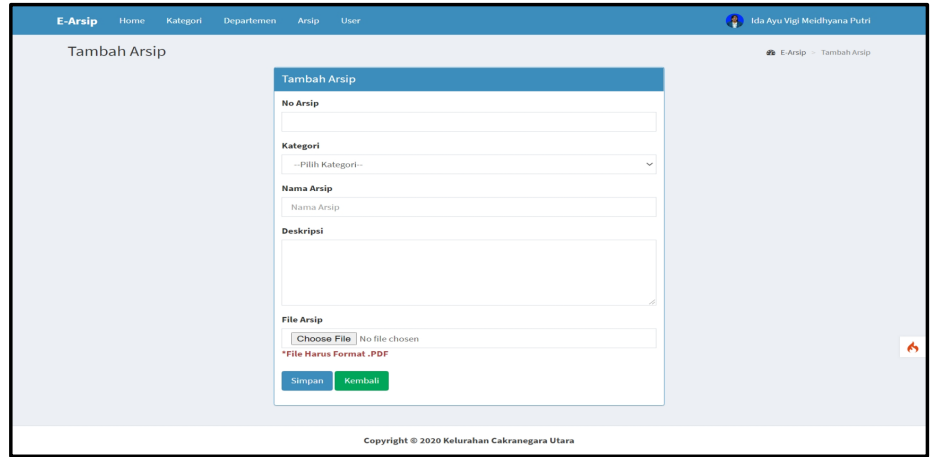

Gambar 17. Implementasi tampilan tambah arsip

Pada Gambar 17 merupakan implementasi tampilan dari halaman tambah data arsip yang akan diisi oleh pegawai ketika mengklik tombol tambah pada tabel Data Arsip di halaman menu Arsip. Pada halaman ini pegawai diminta untuk memasukkan "No Arsip", "Kategori”, "Nama Arsip", "Deskripsi”, dan "File Arsip". Data arsip yang sudah terisi bisa disimpan dengan mengklik tombol simpan.

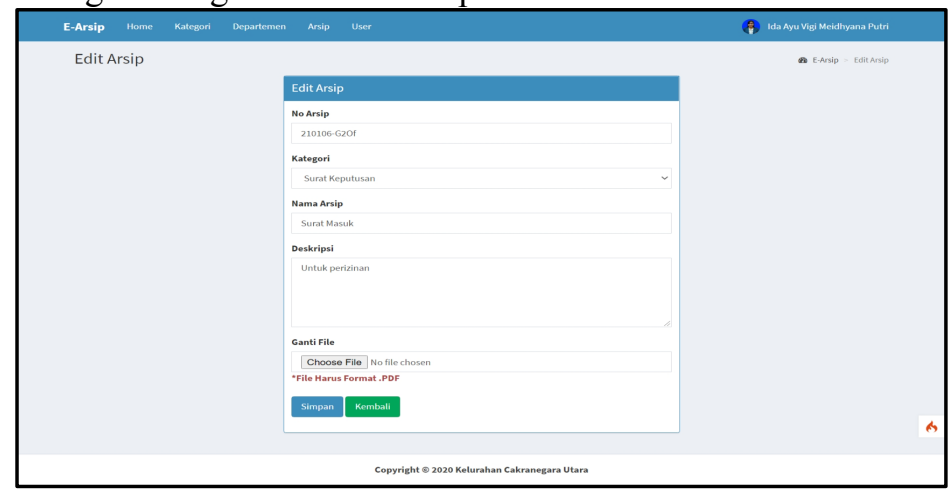

Gambar 18. Implementasi tampilan edit arsip

Pada Gambar 18 merupakan implementasi tampilan dari halaman edit data arsip yang akan diubah oleh pegawai ketika mengklik tombol edit pada kolom action di tabel Data Arsip. Data arsip yang sudah diedit bisa disimpan dengan mengklik tombol simpan.

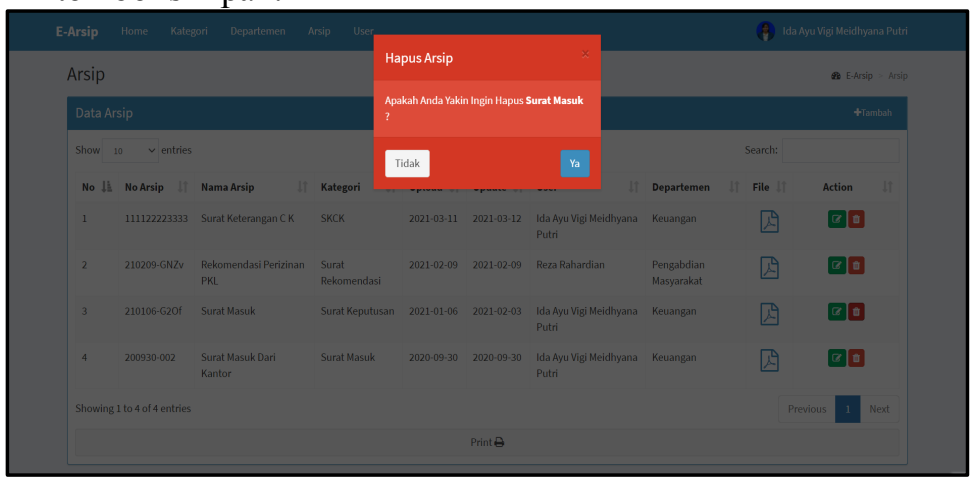

Gambar 19. Implementasi tampilan hapus arsip

Pada Gambar 19 merupakan implementasi tampilan hapus data arsip. Ketika user mengklik tombol hapus berwarna merah pada kolom action maka akan muncul window untuk melakukan hapus data arsip. Pada tampilan ini terdapat tombol "Ya" yang digunakan ketika user yakin akan menghapus data arsip dan tombol "Tidak" yang digunakan ketika user batal melakukan penghapusan pada data arsip.

\subsection{Pengujian Sistem}

Setelah dilakukan implementasi, maka kemudian dilakukan pengujian sistem yang telah dirancang dan dibuat dengan menggunakan pengujian black box. Pengujian black box merupakan metode pengujian yang dilakukan dengan menguji fungsi-fugnsi dari sistem yang dibuat untuk mengetahui fungsi-fungsi yang dibuat sudah terlaksana dengan baik atau tidak [15]. Pengujian ini lebih mengutamakan pengujian pada luar sistem (interface) agar mudah digunakan oleh client. Berdasarkan pengujian black box yang dilakukan dalam menguji seluruh fitur dari sistem 
informasi e-arsip dengan memasukkan berbagai data yang diperlukan, maka dapat diambil kesimpulan bawha fiturfitur yang terdapat dalam sistem informasi e-arsip pada Kelurahan Cakranegara Utara telah berjalan dengan baik.

Selanjutnya dilakukan pengujian sistem dengan pengisian kuisioner untuk menanyakan beberapa responden terkait sistem yang dibuat. Parameter yang digunakan dalam metode ini yaitu:

1. Apakah sistem informasi e-arsip Kelurahan Cakranegara Utara yang dibuat sudah memenuhi kebutuhan?

2. Apakah sistem yang dibuat dapat memudahkan pegawai dalam mengelola data arsip?

3. Apakah sistem yang dibuat mudah digunakan?

4. Apakah sistem sudah bekerja sesuai dengan kegunaannya?

5. Apakah sistem informasi e-arsip yang dibuatkan memiliki tampilan yang sesuai kebutuhan?

Responden akan diberikan pilihan jawaban dari pertanyaan sebelumnya diantaranya:

1. Ya

2. Tidak

Hasil keseluruhan jawaban dari lima responden dilakukan rekapitulasi berdasarkan setiap pertanyaan yang diajukan. Berikut merupakan grafik dari persentase rata-rata jawaban dari empat responden:

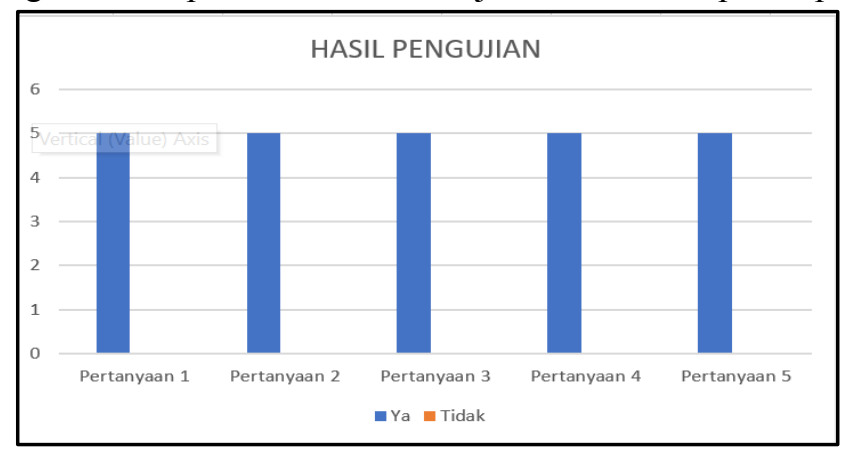

Gambar 20. Persentase hasil pengujian

Gambar 20 merupakan hasil pengujian kuisioner yang dilakukan dengan memberikan pertanyaan kepada lima responden terkait. Hasil tersebut menunjukkan bahwa ke-lima responden menjawab semua pertanyaan dengan "Ya" atau setuju. Sehingga, dapat disimpulkan bahwa dari hasil pengujian tersebut kepuasan reponden terhadap sistem informasi e-arsip Kelurahan Cakranegara Utara yang dirancang dan dibuat $100 \%$ setuju sesuai dengan kebutuhan, fungsi, kinerja dan informasi yang diperlukan.

\section{KESIMPULAN DAN SARAN}

\subsection{Kesimpulan}

Dari kegiatan yang telah dilakukan, didapatkan kesimpulan yaitu :

1. Sistem informasi e-arsip yang dibuat dapat digunakan untuk melakukan pendataan terhadap data-data arsip serta dapat mencetak seluruh data arsip yang telah disimpan di dalam website dengan memiliki 2 pengguna (administrator dan user).

2. Hasil pengujian yang dilakukan dengan mengetahui kepuasan pengguna terhadap sistem yang dibuat yaitu $100 \%$ sesuai dengan kebutuhan, fungsi, kinerja, dan informasi yang dihasilkan.

\subsection{Saran}

Berdasarkan sistem inforamsi e-arsip yang dibuat, dapat diberikan saran yaitu dengan melakukan perbaikan tampilan serta menambahkan beberapa fitur baru seperti dapat menerima surat elektronik melalui website tersebut untuk dapat menunjang kinerja dari sistem dan dapat memudahkan administrator dan user dalam mengelola datadata arsip.

\section{DAFTAR PUSTAKA}

[1] B.K. Williams, S. C. Sawyer, Using Information Technology (Terjemahan Indonesia), Yogyakarta: Andi Offset, 2007.

[2] Darmono, "Sistem Informasi Pelayanan Arsip Pada Dinas Perpustakaan dan Kearsipan Kabupaten Seruyan Menggunakan Borland Delphi 7.0 dan Interbase," Jurnal Penelitian Dosen Fikom (UNDA), Vol. 10, No. 2, November 2019, ISSN : 2088-3595.

[3] A. Kadir, Pengenalan Sistem Informasi, Yogyakarta: CV.Andi Offset, 2014. 
[4] J. Hartono, Analisis dan Desain SIstem Informasi, Yogyakarta: Andi Offset, 2005.

[5] A. Kristanto, Perancangan SI dan Aplikasinya, Yogyakarta: Penerbit Gava Media, 2003.

[6] M. R. Arief, Pemrograman Basis Data Menggunakan Transact-SQL dengan Microsoft SQL Server 2000, Yogyakarta: Andi, 2006.

[7] F. Marisa, Web Programming untuk Membangun Portal, Yogyakarta: CV Budi Utama, 2017.

[8] H. Hartono, Pengertian Website dan Fungsinya, Ilmu Teknologi Informasi, pp.2-7, 2014.

[9] F. T. Yuniko dan F. K. Putra, "Penerapan Teknologi Informasi Web Programming untuk Meningkatkan Pelayanan Publik Dalam Bidang Kebijakan Administrasi Kekematianan," JOISIE (Journal Of Information Systems And Informatics Engineering), 1(1), 13, 2019.

[10] Haviluddin, "Memahami Penggunaan UML (Unified Modelling Language)," Jurnal Informatika Mulawarman, vol. 6, No. 1, Februari 2011, pp. 1-15.

[11] R A. Sukamto dan M. Shalahuddin, Rekayasa Perangkat Lunak Terstruktur dan Berorientasi Objek, Bandung: Informatika, 2014.

[12] Prijambodo, Out of The Boc: Koperasi Tantangan Perubahan Kini dan Masa Depan, Yogyakarta: Phoenix Publisher, 2018.

[13] Sutarman, Membangun Aplikasi Web dengan PHP dan MySQL, Yogyakarta: Penerbit Graha Ilmu, 2003.

[14] M. R. Arief, Pemrograman Web Dinamis Menggunakan PHP \& MySQL, Yogyakarta: Andi, 2011. 